\title{
Microstructural evolution and strain development in Metal Matrix Composites
}

\author{
GEANDIER Guillaume ${ }^{1,2, \mathrm{a}}$, VAUTROT Lilian ${ }^{1,2, \mathrm{~b}}$, SALIB Matthieu ${ }^{1, \mathrm{c}}$, \\ MOUROT Mickäel ${ }^{1}$, DEHMAS Moukrane ${ }^{1,2, \mathrm{~d}}$, DENAND Benoît ${ }^{1,2, \mathrm{e}}$, \\ AEBY-GAUTIER Elisabeth ${ }^{1,2, \mathrm{f}}$ \\ and DENIS Sabine ${ }^{1,2, \mathrm{~g}}$
}

\author{
${ }^{1}$ Institut Jean Lamour - UMR 7198 CNRS - Université de Lorraine - Parc de Saurupt - CS 50840 - \\ 54011 Nancy Cedex France \\ ${ }^{2}$ LabEx DAMAS - Université de Lorraine, Nancy, France \\ aguillaume.geandier@univ-lorraine.fr, blilian.vautrot@univ-lorraine.fr, \\ cmatthieu.salib@univ-lorraine.fr, ${ }^{\mathrm{d}}$ moukrane.dehmas@univ-lorraine.fr, \\ ebenoit.denand@univ-lorraine.fr, ${ }^{f}$ elisabeth.gautier@univ-lorraine.fr, ${ }^{g}$ sabine.denis@univ-lorraine.fr
}

Keywords: metal matrix composite, X-ray diffraction, microstructure, strains, high energy synchrotron radiation.

\begin{abstract}
Composite materials present interesting mechanical properties. The metal provides the toughness and the particles are adding elastic stiffness, strength, hardness and wear resistance. High energy X-ray diffraction has been used to characterize the microstructure evolution of two types of MMCs (titanium and steel matrix) reinforced with TiC particles. Evolutions of mass fraction and mean cell parameters shows the effect of reinforcement on the kinetics and mechanical state of the final composites.
\end{abstract}

\section{Introduction}

Since 1970's [1], composite materials are developed for their interesting mechanical properties. Their development in the last decade is the result of the introduction of micro/nano particles in a metallic matrix. The metal provides the toughness and the particles are adding elastic stiffness, strength, hardness and wear resistance. High specific stiffness and high specific strength are interesting characteristics of Metal Matrix Composites (MMC). These features make it possible to substantially lower the weight and retain high properties. The particles must be carefully chosen for each kind of matrix and are conditioned by a thermodynamic equilibrium between the matrix and the reinforcement [2]. In order to optimize the properties of MMC by thermal treatments, it is necessary to analyze the interactions between the particles and the matrix and their role on the final microstructure [3]. The evolution of the matrix and of the reinforcement were thus analyzed during thermal treatment using in situ high energy X-ray diffraction (HEXRD). In the present contribution, we analyze the structural evolution and strain development in two metal matrix composites with two kinds of matrix: titanium alloys and steels both reinforced with TiC particles.

\section{Samples}

Composites have been produced by Mecachrome company. Ti64-TiC composite contains 10vol\% of $\mathrm{TiC}$ and steel-TiC contains $15 \mathrm{mass} \%$ of TiC. More details on the steel-TiC composite can be found in [3]. A mechanical milling of matrix powders and TiC particles was performed at relatively low energy in order to reduce the size of both components. The consolidation of the composite powders was further realized by hot iso-static pressing (HIP) under a stress of $100 \mathrm{MPa}$ at $920^{\circ} \mathrm{C}$ for Ti64 matrix and $1120^{\circ} \mathrm{C}$ for steel matrix during 4 hours. The micrographs obtained at room temperature after HIP, are given figure 1 and figure 2. The micrographs obtained for Ti64-TiC composite (Fig 1) are given at 

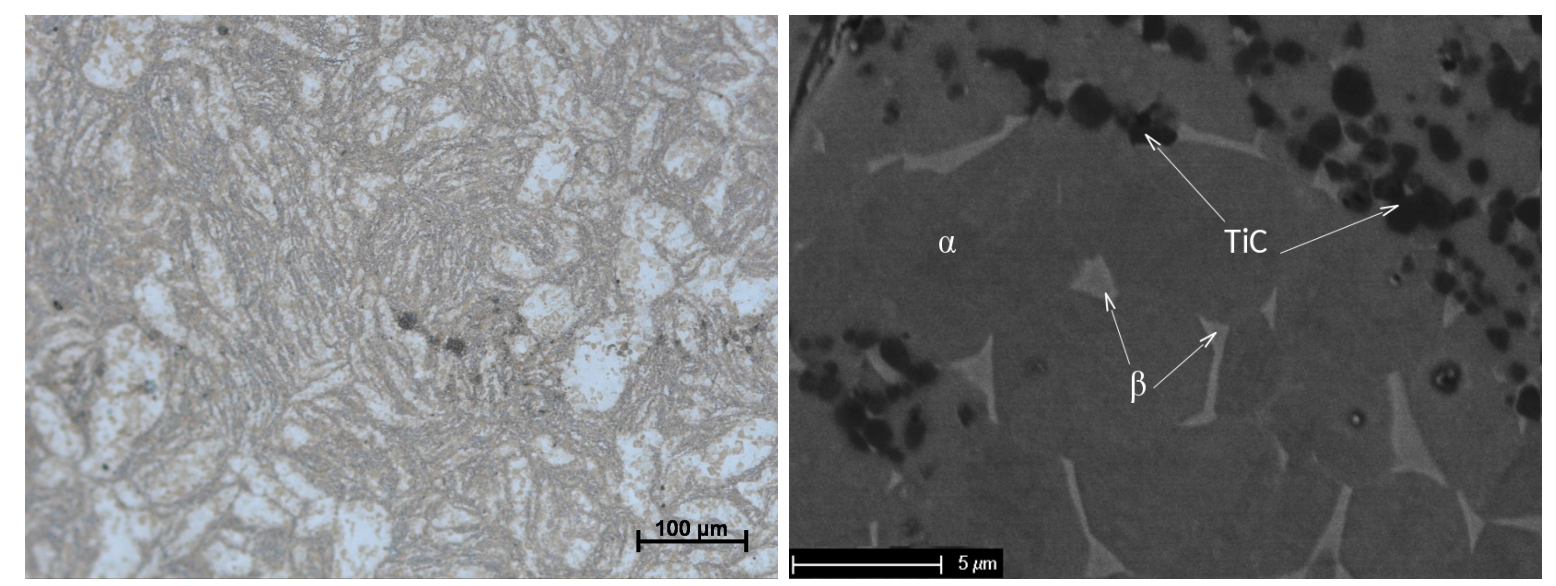

Fig. 1: Microstructure of the Ti64-TiC composite.

two magnifications. At the micrometer scale, the distribution of the phases/components presents some heterogeneity with dark/grey and light areas. The dark/grey areas are related to the presence of TiC particles, while the light areas correspond to a lower concentration or the absence of reinforcement. At higher magnification (SEM image) we distinguish the reinforcement in black and the two phases present in the matrix (beta in white and alpha in grey). The steel/TiC composite presents also a non-

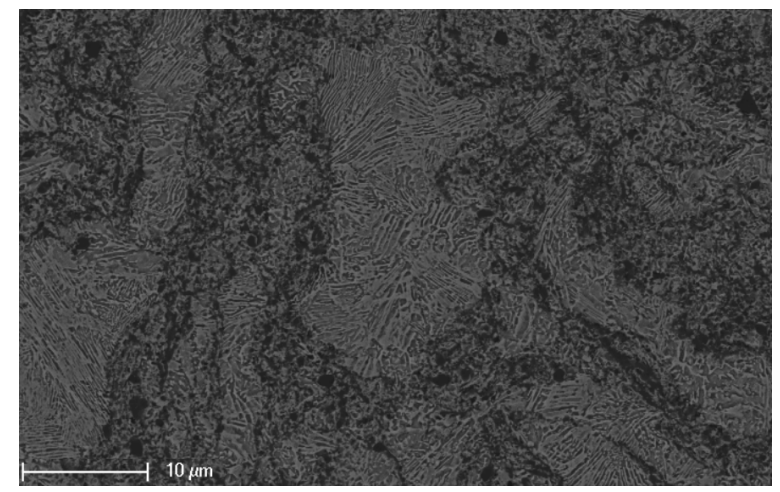

Fig. 2: Microstructure of the steel-TiC composite.

homogeneous distribution of all components with the black components being the TiC particles, the grey area being a mixture of $\mathrm{TiC}$ particles and steel and the lighter area some steel powders without reinforcement [3].

\section{Experimental set-up - High energy X-ray diffraction}

The high energy X-ray diffraction (HEXRD) experiments were performed at the European Synchrotron Radiation Facility (ESRF, Grenoble, France), on the ID15B beam line. The in situ measurements were conducted using high energy $\mathrm{X}$-ray synchrotron radiation diffraction with a monochromatic beam of $87 \mathrm{keV}$. The high energy beam allowed to analyze a large volume of the sample, to be representative of the bulk behavior and to lessen the surface effect $[4,5]$. High energy X-ray diffraction is largely used to determine the mechanical behavior of heavy samples [6]. The combination between the high flux from synchrotron source, a large area detector and the high energy allows to make in situ analysis of phenomena with a time scale of one second or less in the bulk. Using the phase selectivity of the X-ray diffraction we are able to extract parameters for each phase present in the composite. For our experiments, the samples had a thickness of $3 \mathrm{~mm}$ in the beam direction. The beam size was fixed 
to $0.4 \times 0.4 \mathrm{~mm}^{2}$. Each sample was heated using a radiant furnace allowing to heat up to $1000^{\circ} \mathrm{C}$. A thermocouple was spot-welded on the sample surface leading to the measurement of temperature and allowing the control of the heating conditions. XRD patterns were recorded by a flat CCD detector (pixium 4700), with one image every $3.5 \mathrm{~s}$ ( $1 \mathrm{~s}$ exposure $+2.5 \mathrm{~s}$ readout time). Data have been corrected and reduced to ( $2 \theta$, intensity) patterns using fit2d software [7] suitable for Rietveld analysis $[8,9]$. Details can be found in [5].

\section{Titanium matrix composite}

Kinetics of phase transformation. An example of the evolution of phase fraction is given for Ti64 matrix composite (Fig. 3). After HIP, a mixture of three phases is characterized, consisting of $83 \%$ of $\alpha$ phase, $5.5 \%$ of $\beta$ and $11.5 \%$ of TiC. Phase transformations start around $600^{\circ} \mathrm{C}$. Between $600^{\circ} \mathrm{C}$ and $720^{\circ} \mathrm{C}$, the kinetics of phase transformation $\alpha$ to $\beta$ is very slow. In this temperature range, the amount of $\mathrm{TiC}$ increases, with a maximum of $12.5 \%$ at $720^{\circ} \mathrm{C}$. Between $720^{\circ} \mathrm{C}$ and $920^{\circ} \mathrm{C}$, the $\alpha \rightarrow \beta$ transformations kinetics is accelerated. On dwell, the three phases are still present (56\% $\alpha$ phase, $32 \% \beta$ phase and $12 \%$ TiC). During the dwell, we can observe some oscillations that are due to the non-perfect temperature control. The amount of $\alpha$ phase is slightly decreasing to reach a value $51 \%$ at the end of dwell. These amounts are different from the ones expected in a Ti64 alloy. Indeed, in a Ti64 alloy, the amount of phases present at $920^{\circ} \mathrm{C}$ would be $46 \mathrm{vol} \%$ of $\alpha$ and $54 \mathrm{vol} \%$ of $\beta$ [10]. These values are significantly different from the ones measured. Therefore the $\alpha \rightarrow \beta$ transformation domain in the Ti64/TiC composite is shifted toward higher temperatures. The main reason of the shift is the presence of carbon coming from TiC and oxygen introduced by the process. During cooling,

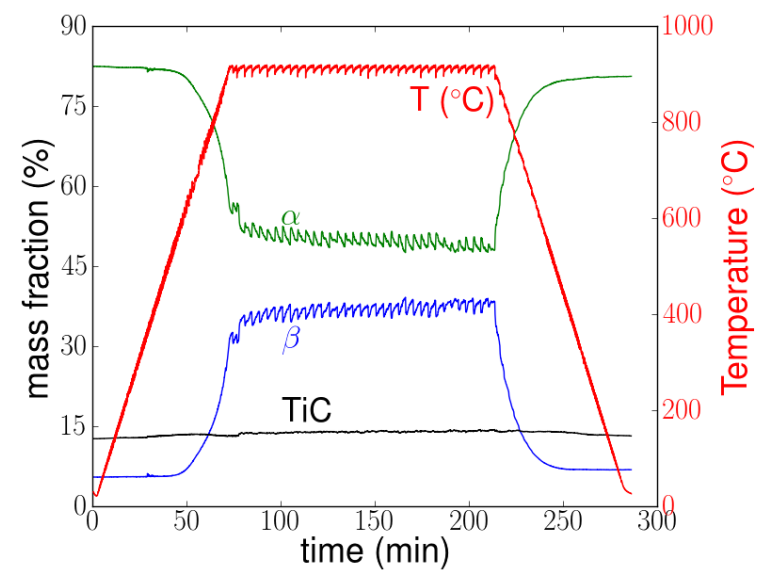

Fig. 3: Mass fraction evolution during heat thermal for Ti64/TiC composite.

the amount of $\alpha$ increases very quickly until $680^{\circ} \mathrm{C}$ and more slowly between $680^{\circ} \mathrm{C}$ and $550^{\circ} \mathrm{C}$. For temperatures lower than $550^{\circ} \mathrm{C}$, the volume fraction of each phase remains nearly constant whereas $\mathrm{TiC}$ amount slightly decreases throughout the cooling. After the heat treatment, the phase ratios are nearly similar to those present in the initial state. However, the amount of TiC increased by about $1 \%$ vol. From Ti-C phase diagram and for a given composition, small changes in $\mathrm{TiC}$ amount can be expected when temperature varies [11]. Moreover, TiC can be enriched in oxygen [12].

lattice parameters evolution. Rietveld analysis allowed to determine the lattice parameters for each phase and their evolution during the thermal treatment. During the Rietveld analysis, diverse parameters are adjusted as: background, zero shift for the whole diagram and for each phase, scale factor, peak shape and width, lattice parameters and overall isotropic displacement. For Rietveld analysis and quantitative evaluations, crystallographic structures need to known. The structure of our phase 
are: TiC (cubic FM-3M), Fe- $\alpha$ (cubic IM-3M), Fe- $\gamma$ (cubic FM-3M), Fe- $\alpha$ " (cubic I4/MMM), $\mathrm{Fe}_{3} \mathrm{C}$ (orthorhombic PNMA), Ti- $\alpha$ (hexagonal P63/MMC) and Ti- $\beta$ (cubic IM-3M).

The relative lattice parameter variations are determined using equation 1:

$$
\frac{d a^{i}}{a_{0}^{i}}=\frac{\left(a^{i}-a_{0}^{i}\right)}{a_{0}^{i}}
$$

where $\mathrm{a}^{i}$ is the lattice parameter of phase $\mathrm{i}$ for the given image number and $\mathrm{a}_{0}^{i}$ the lattice parameter of phase $i$ in the initial state (time 0 ). Evolutions of relative lattice parameters for Ti64/TiC composite are presented on figure 4. For TiC, the relative lattice parameter evolution is nearly linear during heating as well as during cooling. On the contrary large changes in the slope are observed for the relative lattice parameters of the matrix. The relative lattice parameters of each phase of the matrix vary linearly
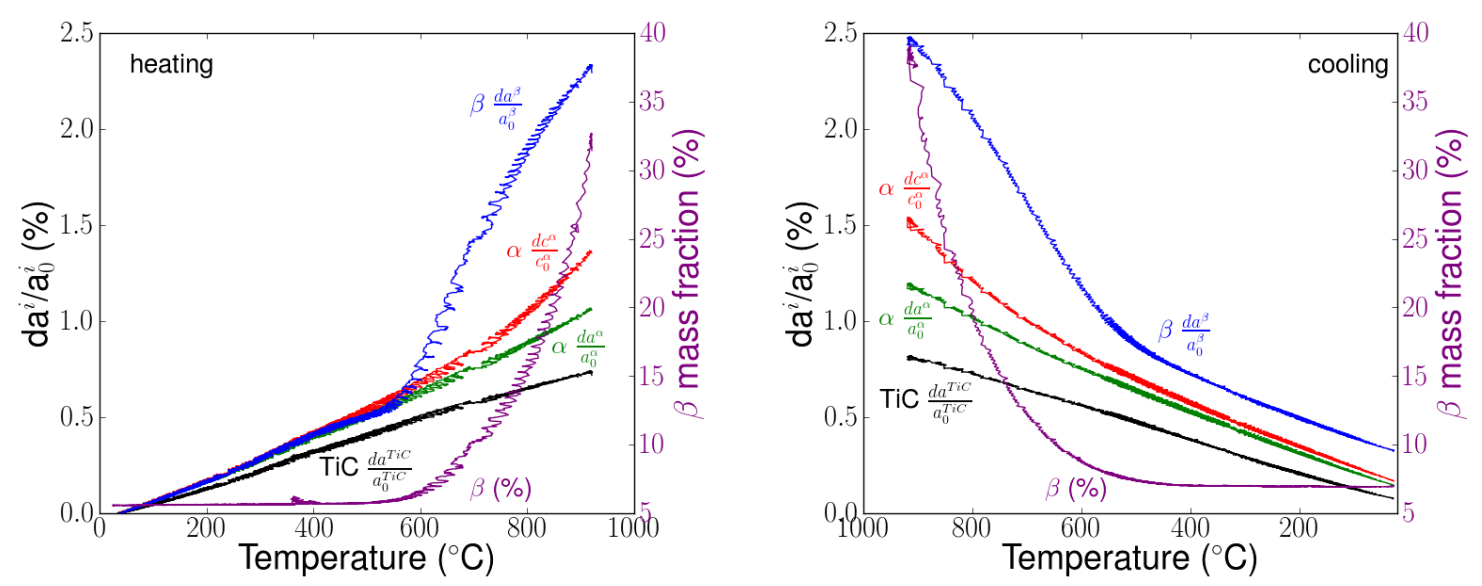

Fig. 4: Cell parameters relative evolution during heat thermal for Ti64/TiC composite.

between room temperature and $600^{\circ} \mathrm{C}$. For the $\alpha$ phase and temperatures higher than $630^{\circ} \mathrm{C}$, both relative lattice parameters ( $\mathrm{a}$ and c) increase, but non-linearly. For $\mathrm{da}^{\alpha} / \mathrm{a}_{0}^{\alpha}$ the slope increases slightly until $920^{\circ} \mathrm{C}$, while $\mathrm{dc}^{\alpha} / \mathrm{c}_{0}^{\alpha}$ presents higher slope variations at temperatures higher than $505^{\circ} \mathrm{C}$. During cooling, $\mathrm{da}^{\alpha} / \mathrm{a}_{0}^{\alpha}$ and $\mathrm{dc}^{\alpha} / \mathrm{c}_{0}^{\alpha}$ are similar to those observed during heating. For the $\beta$ phase, $\mathrm{da}^{\beta} / \mathrm{a}_{0}^{\beta}$ increases linearly up to $550^{\circ} \mathrm{C}$. Between $550^{\circ} \mathrm{C}$ and $920^{\circ} \mathrm{C} \mathrm{da}^{\beta} / \mathrm{a}_{0}^{\beta}$ increases abruptly reaching a value more than twice the value obtained between $20^{\circ} \mathrm{C}$ and $500^{\circ} \mathrm{C}$. This strong variation is mainly associated with the partial $\alpha \rightarrow \beta$ phase transformation and the associated change in chemical composition of $\beta$ [13]. On cooling the behavior is symmetrical. These behaviors for $\alpha$ and $\beta$ phases are similar to the ones obtained for titanium alloys $[13,14]$. The thermal expansion coefficient of each phase was estimated in the linear part of the evolution. Results are reported in table 1 . These values TiC are close to the literature value: $8.6 \times 10^{-6} \cdot \mathrm{K}^{-1}$ [15] for TiC and higher for Ti64 that are commonly between to 8.5 and $10 \times 10^{-6} \cdot \mathrm{K}^{-1}$ from 20 and $500^{\circ} \mathrm{C}[16]$.

Table 1: Experimental coefficient of thermal expansion for Ti64/TiC composite during heating and cooling.

\begin{tabular}{|c|c|c|c|c|c|}
\hline \multicolumn{3}{|c|}{ heating } & \multicolumn{3}{c|}{ cooling } \\
\hline Phase & $\alpha\left(10^{-6} \mathrm{~K}^{-1}\right)$ & T range $\left({ }^{\circ} \mathrm{C}\right)$ & Phase & $\alpha\left(10^{-6} \mathrm{~K}^{-1}\right)$ & T range $\left({ }^{\circ} \mathrm{C}\right)$ \\
\hline Ti64 $\alpha / \mathrm{a}$ & 10.8 & $30-630$ & Ti64 $\alpha / \mathrm{a}$ & 10.7 & $40-660$ \\
\hline Ti64 $\alpha / \mathrm{c}$ & 11.3 & $30-505$ & Ti64 $\alpha / \mathrm{c}$ & 10.5 & $40-500$ \\
\hline Ti64 $\beta$ & 10.9 & $30-505$ & Ti64 $\beta$ & 11.3 & $40-450$ \\
\hline TiC & 8.9 & $40-895$ & TiC & 8.2 & $40-895$ \\
\hline
\end{tabular}




\section{Steel matrix composite}

For the steel-TiC composite we mainly focus on the phase transformations occurring during cooling. At the end of the heating and dwell at $1000^{\circ} \mathrm{C}$, the steel-TiC composite is composed of two phases: austenite $(81.6 \%)$ and $\mathrm{TiC}(18.4 \%)$. The behavior of the phases is analyzed for two cooling conditions from $1000^{\circ} \mathrm{C}$ to room temperature; Condition I, ferrite and pearlite formation in the metallic matrix with a slow cooling at $0.5^{\circ} \mathrm{C} / \mathrm{s}$; Condition II, martensite formation in the metallic matrix with a fast cooling at $5^{\circ} \mathrm{C} / \mathrm{s}$.

Kinetics of phase transformation. The mass fraction evolution of each phase versus temperature are given on figure 5 for cooling at $0.5^{\circ} \mathrm{C} / \mathrm{s}$ (condition I, fig. $5(\mathrm{a})$ ) and $5^{\circ} \mathrm{C} / \mathrm{s}$ (condition II, fig. $5(\mathrm{~b})$ ). For both cooling conditions, only austenite $(\gamma)$ and TiC are present on dwell. For condition I, a very
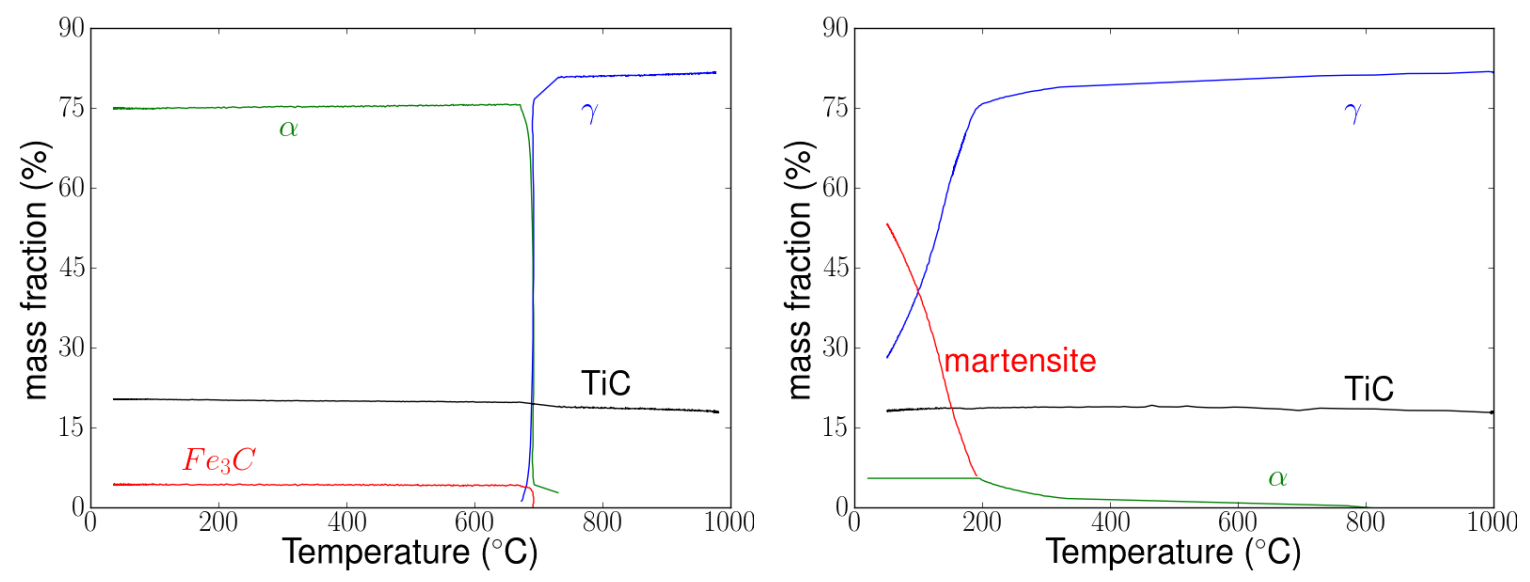

Fig. 5: (a) Mass fraction evolution during cooling $\left(1000^{\circ} \mathrm{C}\right.$ to $20^{\circ} \mathrm{C}$ at $\left.0.5^{\circ} \mathrm{C} / \mathrm{s}\right)$ and (b) mass fraction evolution during cooling $\left(1000^{\circ} \mathrm{C}\right.$ to $20^{\circ} \mathrm{C}$ at $\left.5^{\circ} \mathrm{C} / \mathrm{s}\right)$ for steel/TiC composite.

slight increase in the mass fraction of $\mathrm{TiC}$ is observed until $780^{\circ} \mathrm{C}$ while $\gamma$ amount decreases. Ferrite $(\alpha)$ is formed at $780^{\circ} \mathrm{C}$ and the formation of pearlite $\left(\alpha+\mathrm{Fe}_{3} \mathrm{C}\right)$ occurs between $690^{\circ} \mathrm{C}$ and $670^{\circ} \mathrm{C}$. In that last temperature range, the $\mathrm{TiC}$ amount slightly increases. The change in $\mathrm{TiC}$ amounts is due to differences in carbon solubility in austenite and ferrite and non-stoechiometry of the TiC phase. For that cooling rate, the transformation of the matrix leads to a mixture of ferrite and pearlite. The amount of all phases remains constant between until $670^{\circ} \mathrm{C}$ and room temperature.

For condition II, ferrite $(\alpha)$ appears also at $780^{\circ} \mathrm{C}$. The amount of this $\mathrm{BCC}$ structure increases slightly until $200^{\circ} \mathrm{C}\left(5\right.$ mass $\%$ at $\left.200^{\circ} \mathrm{C}\right)$. At temperatures lower than $200^{\circ} \mathrm{C}$, the martensite (tetragonal structure) is formed. The TiC amount remains stable during cooling. As martensite and ferrite have nearly the same crystallographic structure and due to the angular resolution of the detector, it is not possible to distinguish the ferrite from martensite at low temperature. We have assumed that ferrite remains constant when the martensite transformation begins. For condition II, the transformation of the matrix leads to a mixture of austenite, ferrite and martensite.

Cells parameters evolution. The lattice parameters evolutions during cooling for the steel/TiC composite are given figure 6 for condition I and figure 7 for condition II. For condition I, (Fig. 6), the lattice parameters evolution is linear between $1000^{\circ} \mathrm{C}$ and $700^{\circ} \mathrm{C}$, when no phase transformation occurs or at the very early stages of the matrix transformation. During the pearlite formation $\left(690^{\circ} \mathrm{C}\right.$ $670^{\circ} \mathrm{C}$ ), the austenite parameter decreases while the ferrite parameter increases. The TiC lattice parameter presents also an increase during this step of the matrix phase transformation. During the further cooling, we clearly evidence a non-linearity of the cells parameters of ferrite and $\mathrm{TiC}$ at temperatures lower than $300^{\circ} \mathrm{C}$.

The CTE of the present phase was estimated in different temperature ranges. Results are reported in table 2. These values clearly highlight the changes in the apparent CTE. Indeed, the CTE value of TiC 


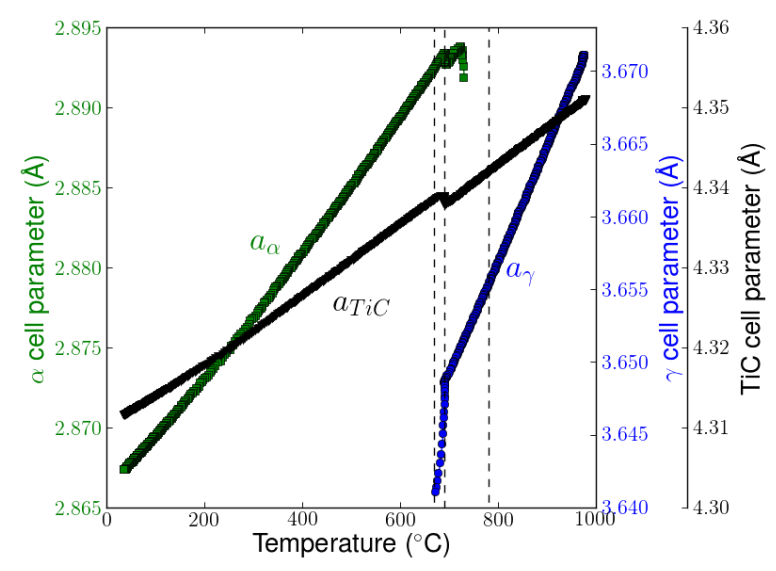

Fig. 6: Lattice parameters evolution during cooling $\left(1000^{\circ} \mathrm{C}\right.$ to $20^{\circ} \mathrm{C}$ at $\left.0.5^{\circ} \mathrm{C} / \mathrm{s}\right)$ for steel/TiC composite.

Table 2: Experimental coefficient of thermal expansion for steel-TiC composite during cooling $\left(1000^{\circ} \mathrm{C}\right.$ to $20^{\circ} \mathrm{C}$ at $\left.0.5^{\circ} \mathrm{C} / \mathrm{s}\right)$.

\begin{tabular}{|c|c|c|c|c|c|}
\hline Phase & $\alpha\left(10^{-6} \mathrm{~K}^{-1}\right)$ & T range $\left({ }^{\circ} \mathrm{C}\right)$ & Phase & $\alpha\left(10^{-6} \mathrm{~K}^{-1}\right)$ & T range $\left({ }^{\circ} \mathrm{C}\right)$ \\
\hline austenite & 22.1 & $750-900$ & TiC & 10.7 & $720-900$ \\
\hline ferrite & 14.7 & $300-600$ & TiC & 10.4 & $300-600$ \\
\hline ferrite & 12.2 & $100-300$ & TiC & 9.1 & $100-300$ \\
\hline
\end{tabular}

is larger than the one measured in the Ti64-TiC composite $\left(8.6 \times 10^{-6} \mathrm{~K}^{-1}\right)$, and generally reported in the literature [15]. It decreases significantly as temperature decreases. For condition II, from the beginning of cooling and until the martensite formation, the lattice parameters of each phase decrease continuously with slight changes in the slope.
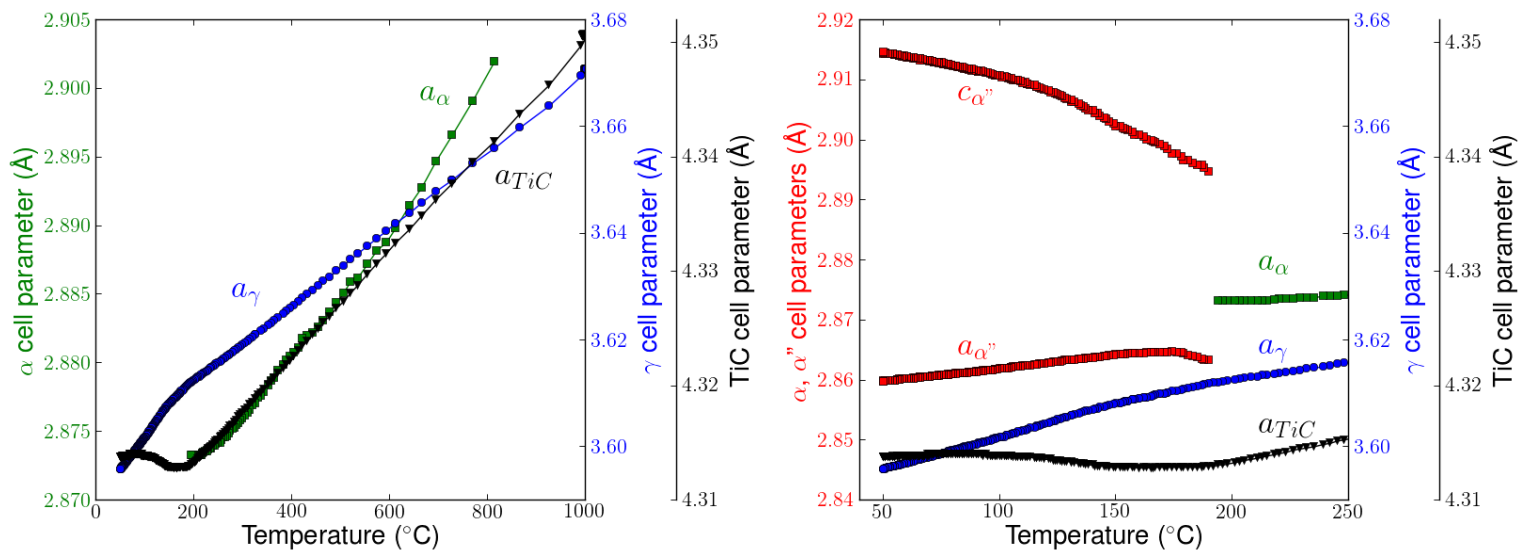

Fig. 7: Lattice parameters evolution during cooling $\left(1000^{\circ} \mathrm{C}\right.$ to $20^{\circ} \mathrm{C}$ at $\left.5^{\circ} \mathrm{C} / \mathrm{s}\right)$ for steel/TiC composite.

During the martensite formation, as austenite content reaches $28 \%$, its lattice parameter decreases and deviates significantly from linearity; meanwhile the TiC lattice parameter increases also deviates from linearity and even increases. This is also highlighted in fig. 7 giving in addition the lattice parameters of martensite, for the temperature range $20^{\circ} \mathrm{C}-300^{\circ} \mathrm{C}$. The TiC lattice parameter seems to be stagnant between $200^{\circ} \mathrm{C}$ and $150^{\circ} \mathrm{C}$, and further increases until $50^{\circ} \mathrm{C}$. For the lattice parameters of 
martensite, an increase of $\mathrm{a}_{\alpha^{\prime \prime}}$ and $\mathrm{c}_{\alpha^{\prime \prime}}$ is observed between $180^{\circ} \mathrm{C}$ and $170^{\circ} \mathrm{C}$. As temperature is further decreased and martensite amount increases, $\mathrm{a}_{\alpha^{\prime \prime}}$ parameter decreases while $\mathrm{c}_{\alpha^{\prime \prime}}$ parameter increases.

Table 3: Experimental coefficient of thermal expansion for steel-TiC composite during cooling $\left(1000^{\circ} \mathrm{C}\right.$ to $20^{\circ} \mathrm{C}$ at $\left.5^{\circ} \mathrm{C} / \mathrm{s}\right)$.

\begin{tabular}{|c|c|c|}
\hline Phase & $\alpha\left(10^{-6} \mathrm{~K}^{-1}\right)$ & $\left({ }^{\circ} \mathrm{C}\right)$ \\
\hline austenite & 20.4 & $300-500$ \\
\hline ferrite & 15.1 & $300-500$ \\
\hline TiC & 10.9 & $300-500$ \\
\hline
\end{tabular}

For the martensite, both parameters goes to tension at the beginning of the transformation, its means an increases of the lattice volume. In the same time TiC parameters seems to be stagnant. With cooling down and transformation advancement, $\mathrm{c}_{\alpha^{\prime \prime}}$ parameters increases and $\mathrm{a}_{\alpha^{\prime \prime}}$ decreases. In the same time, TiC parameters goes in tension. The thermal expansion coefficient of the present phase was estimated in the linear part of the evolution, results are reported in table 3.

\section{Summary}

High energy diffraction is a powerful tool to highlight the microstructure evolution during thermal treatments for composite materials. Evolution of the phase fraction and lattice parameters during thermal treatments of metal matrix composites (titanium and steel matrix) shown that their exist chemical exchange between the matrix and the reinforcement. These exchanges modify the phase transformation kinetics and the mechanical state of the final composites. Phases with high TEC constraint the whole structure and modify the strain in the other pahses. Further work will focus on the stress determination and calculations by FEM, in all the phases of the composites during the thermal treatment to show the effect of the phase transformations on the internal and residual stresses.

\section{Acknowledgments}

The authors gratefully acknowledge Mecachrome for supplying the materials, the direction Générale des Entreprises (DGE) for financial support in the AMETIS program and the European Synchrotron Radiation Facility (ESRF) for provision of beamtime at beamline ID15B. This work was supported by the French State through the program "Investment in the future" operated by the National Research Agency (ANR) and referenced by ANR-11-LABX-0008-01 (LabEx DAMAS).

\section{References}

[1] L. Guozhen, Z. Quanpu and D. Ju: Titanium 95, Vol. 3 (1995), p. 2704-2713

[2] T. Saito, T. Furuta and H. Takamiya : Titanium'95, Vol. 3 (1995), p. 2763-2770

[3] M. Mourot, A. Courleux, M. Dehmas, E. Gautier, G. Geandier, O. Dezellus, J.C. Viala, O. Martin, O., N. Karnatak and F. Danoix: Solid State Phenomena, Vol. 172-174 (2011), p. 747-752

[4] T. Tschentscher and P. Suortti: Journal of Synchrotron Radiation, Vol. 5 (1998), p. 286-292

[5] G. Geandier, E. Aeby-Gautier, A. Settefrati, M. Dehmas and B. Appolaire, B: Comptes Rendus Physique, Vol. 13 (2012), p. 257-267

[6] K.D. Liss, A. Bartels, A. Schreyer and H. Clemens: Textures and Microstructures, Vol. 35 (2003), p. $219-252$

[7] A.P. Hammersley, S.O. Svensson, A. Thompson, H. Graafsma, A. Kvick and J.P. Moy: Review of Scientific Instrument, Vol. 66 (1995), p. 2729-2733

[8] H.M.A. Rietveld: Journal of Applied Crystallography, Vol. 2 (1969), p. 65-71

[9] J. Rodriguez-Carvajal: Physica B, Vol. 192 (1993), p. 55-69 
[10] M. Dehmas, R. Katemi, B. Appolaire, E. Aeby-Gautier, B. Denand and S. Audion: Ti-2011 12th world conference on Titanium, Beijing, china (2011).

[11] K. Frisk: Computer Coupling of Phase Diagrams and Thermochemistry, Vol 27 (2003), p. 367-373

[12] T. M. T. Godfrey, A. Wisbey, P. S. Goodwin, K. Bagnall, and C. M. Ward-Close: Materials Science and Engineering: A, Vol. 282, no. 1-2 (2000), p. 240-250

[13] F. Bruneseaux, E. Aeby-Gautier, G. Geandier, J. Teixeira, B. Appolaire, P. Weisbecker and A. Mauro: Materials Science and Engineering A, Vol 476 (2008), p. 60-68

[14] E. Aeby-Gautier, F. Bruneseaux, J. Teixeira, B. Appolaire, G. Geandier and S. Denis: Journal of Materials, January (2007), p. 55-58

[15] K. Wokulska: Journal of Alloys and Compounds, Vol 264 (1998), p. 223-227

[16] J.W. Elmer, T.A. Palmer, S.S. Babu and E.D. Specht: Materials Science and Engineering A, vol 391 (2005), p. 104-113 